Relations industrielles

Industrial Relations

\title{
The Ontario Labour Court 1943-1944, by John A. Whilles, Research and Current Issues Series no. 37, Kingston, Ontario, Industrial Relations Centre, Queen's University, 1979, 255 pp.
}

\section{Don Carter}

Volume 34, numéro 3, 1979

URI : https://id.erudit.org/iderudit/028999ar

DOI : https://doi.org/10.7202/028999ar

Aller au sommaire du numéro

Éditeur(s)

Département des relations industrielles de l'Université Laval

ISSN

0034-379X (imprimé)

1703-8138 (numérique)

Découvrir la revue

Citer ce compte rendu

Carter, D. (1979). Compte rendu de [The Ontario Labour Court 1943-1944, by John A. Whilles, Research and Current Issues Series no. 37, Kingston, Ontario, Industrial Relations Centre, Queen's University, 1979, 255 pp.] Relations industrielles / Industrial Relations, 34(3), 621-623.

https://doi.org/10.7202/028999ar

Tous droits réservés @ Département des relations industrielles de l'Université Laval, 1979
Ce document est protégé par la loi sur le droit d'auteur. L'utilisation des services d’Érudit (y compris la reproduction) est assujettie à sa politique d'utilisation que vous pouvez consulter en ligne.

https://apropos.erudit.org/fr/usagers/politique-dutilisation/ 
realistically can lead to legislative proposals that would do more harm than good. His comments also apply in part to the more recent recommendations of the Committee on the Costs of Education to base teacher compensation on province-wide job evaluation and comparison with selected private sector employers.

In general, Downie's book is excellent reading for those involved in any aspect of education policy evaluation and research. The book also appears to be useful as background material for practitioners in the field. Every teacher or trustee at the bargaining table would be well advised to have read it thoroughly. In terms of Downie's "educational" objectives, however, the book is less useful for the public. If Mr. and Mrs. John Q. want to know why Johnny's teachers are on strike, they will find Downie's book a lot of work to get an answer.

Finally, I would like to comment on two relatively minor annoyances in the book. The lack of an index is one; its use as a reference work is severely restricted as a result. Inadequate proofreading is the second; the book is liberally sprinkled with annoying errors that get in the reader's way.

These drawbacks, however, should not detract from the book's achievements. In this work Downie has presented the kind of analysis which is sorely needed in the field of industrial relations. It will be a benchmark for others in the discipline, and a classic for those concerned with education in the public schools of Ontario.

\section{John B. KERVIN}

\section{University of Toronto}

The Ontario Labour Court 1943-1944, by John A. Willes, Research and Current Issues Series no. 37, Kingston, Ontario, Industrial Relations Centre, Queen's University, 1979, $255 \mathrm{pp}$.

An early, and interesting, step in the evolution of the administration of Canadian collective bargaining law was the formation of the Ontario Labour Court in 1943. Under the Collective Bargaining Act, 1943, the first piece of legislation in Ontario to be styled along the lines of the Wagner Act, a division of the Trial Division of the High Court was given the responsibility for administering Ontario's new collective bargaining structure. During its brief, ten-month life, the Labour Court performed functions similar to those now carried out by labour boards - assessing the legitimacy of bargaining agents, describing appropriate bargaining units, and determining whether bargaining agents enjoyed the support of employees in those bargaining units. Not only was this the first time in Canada that collective bargaining legislation provided a special structure for its administration, it was the last occasion where that administrative structure was borrowed from the provincial superior courts.

The first part of this monograph sets out the labour relations and political conditions leading to the establishment and demise of the Labour Court, describing the operation of the Court during its brief life and assessing the contribution that it made to labour relations. The concluding chapter of the first part explores the question of whether a Labour Court might now be a suitable vehicle for the administration of collective bargaining law. The second part of the book, comprising 171 pages, contains background material: - the full text of the Court's most significant decisions; the report of the select committee leading up to the Collective Bargaining Act, 1943; the statute itself; and a table of all matters coming before the Board.

During its short existence the Court dealt almost entirely with problems relating to the acquisition of bargaining rights. This emphasis is not surprising, given the high degree of organizing activity on the part of the major labour organizations at that time. One of the major problems at that time was the presence of "employee associations" as rivals to the trade unions affiliated with the major labour organizations. Since proof of the degree of employer domination necessary to disqualify such associations as trade unions 
was difficult to establish, the Court usually left it to employees to decide between rival organizations by means of a vote conducted by the Court's Registrar. Another problem often arising before the Court concerned the extent to which craft units should be permetted in industrial plants. It is interesting to observe that the Court appeared to give wider recognition to such craft units than would be given by labour boards today. Managerial exclusions also appeared to be treated somewhat differently at that time, extending as far as supervisory employees responsible for the quality and quantity of the work of others. Although the Court had a jurisdiction to deal with unfair labour practices and to interpret collective agreement differences, these matters did not form a significant part of the Court's case load during the ten months of its existence.

Of interest is the major role played by the Court's Registrar, Jacob Finkelman. The High Court judges, apparently, did not feel comfortable with the idea of performing many of the "administrative" tasks involved in the application of collective bargaining legislation. As a result, many of these tasks were left to the Registrar who was given wide authority to supervise the conduct of representation votes - an authority that required him to establish the voting constituency and determine the eligibility of employees to vote. In many cases the basic bargaining unit was defined by the Registrar in consultation with the parties, and critical matters such as the identification of confidential and managerial employees and the eligibility of temporary and part-time employees appears to have been entirely in the hands of the Registrar.

There is no question that the Court played a significant role in establishing a legal structure for collective bargaining in Ontario. The short life of the Court coincided with a period of rapid growth in the organization of industrial employees in Ontario. While the study does not provide figures as to the number of employees for whom trade unions acquired bargaining rights during this period, it is evident from the list of cases brought before the Court that some very large bargaining units must have been established. In a short time, moreover, the Court was able to devise a workable set of policies and procedures to govern the acquisition of bargaining rights. The influence of many of these policies and procedures can be seen in the processes of labour boards today.

Despite these achievements, the Labour Court did not gain acceptance by organized labour, a fact that contributed to its early demise. The trade unions regarded the Court as being overly formal and lacking in labour relations experience - an impression that the Court did little to dispel. Although it had a discretion to do otherwise, the Court ruled that any trade union appearing before it was required to do so through legal counsel. The trade unions regarded their own representatives as capable of representing them, and resented having to pay lawyers' fees from their often meagre funds. Labour's criticisms, combined with the need to establish a joint federal-provincial structure for the administrative of collective bargaining legislation during war-time, led to the displacement of the Labour Court by the Ontario Labour Relations Board in early 1944. The first Chairman of the Board was Jacob Finkelman, the Court's former Registrar.

The author has done an excellent job of placing the Labour Court in the political and labour relations context of the early 1940s. The events leading up to the formation of the Select Committee, the considerations underlying its recommendations, and the operation of the Court itself make for interesting reading. The author's interviews with many of those involved have led to some interesting insights about the Court, and about the practice of labour relations at that time.

The author's analysis of the contribution that the Court made to labour relations is also of value. Less convincing, however, is the argument made in the final chapter that a labour court might be a suitable structure for 
the administration of contemporary collective bargaining legislation. At a time when trade unions are complaining that labour boards are too legalistic and formal, it is surprising to see the argument made for a return to the more formal procedure of a court. The author, moreover, appears to underestimate the importance of the representative members from labour and management in the decisionmaking of the labour boards. The board members, who bring to the Board extensive labour relations experience, do have a significant influence on labour board decisions an influence that would not be present in a labour court. The author, however, does recognize this problem, proposing that administrative matters be left to a tri-partite board that might be advisory to the court, which would deal with more fundamental matters. Such a structure, though, would be far too cumbersome to process cases with the expedition required in labour relations. One can only conclude that the author does not recognize the lesson of the first Labour Court - that a purely judicial structure is not well suited for the administration of labour relations laws.

Don CARTER

Queen's University

L'indexation des salaires dans les pays industrialisés à économie de marché, Genève, Bureau international du travail, 1978, $67 \mathrm{pp}$.

Cette monographie publiée par le Bureau international du travail comprend trois parties. Le premier chapitre traite des modalités techniques de l'indexation des salaires à un indice du coût de la vie. Les chapitres II à $\mathrm{V}$ décrivent la situation des différents pays industrialisés selon que l'indexation est généralisée, limitée, presqu'inexistante ou qu'elle constitue un élément d'une politique publique de revenus. Enfin, un dernier chapitre présente une synthèse des attitudes patronales, syndicales et gouvernementales face à l'indexation des salaires dans les pays étudiés.
Au chapitre I, après une brève discussion des notions de rémunération et de coût de la vie, on trouve un examen assez complet des méthodes d'indexation des salaires: variable à ajuster, périodicité des ajustements, indice utilisé, période de référence, forme et montant d'ajustement. Il est un problème assez aigu qui n'est pas mentionné, celui de l'intégration de l'indemnité de vie chère au salaire régulier.

Les chapitres suivants contiennent des renseignements intéressants mais assez généraux sur l'utilisation de l'indexation des salaires au coût de la vie dans les conventions collectives de plusieurs pays. La catégorisation des expériences nationales est révélatrice de l'influence exercée par certains facteurs sur le phénomène de l'indexation: le contexte historique, le degré de centralisation de la négociation, le degré d'intervention étatique dans la distribution des revenus, la maturité du régime de relations de travail, etc... Bien que le document s'en tienne au niveau descriptif, de nombreuses hypothèses de recherche sautent aux yeux du lecteur attentif et intéressé à la théorie des sytèmes de relations industrielles.

Bref, il s'agit d'une brochure utile, qui devrait intéresser surtout le profane en la matière, désireux de se renseigner sur le phénomène de l'indexation des salaires au coût de la vie au plan international.

Claude RONDEAU

Unịversité Laval

Using the Social Sciences, by Albert Cherns, London, Routledge and Kegan Paul, 1979, $502 \mathrm{pp}$.

Social sciences may contribute to policy making by providing practitioners with basic concepts and theories about man and society, delivering data and devising technical solutions to problems. According to Cherns, "by increasing the policy-maker's knowledge and understanding of the system in which he is operating and the characteristics and poten- 